\title{
SISTEM PENDUKUNG KEPUTUSAN PENILAIAN KINERJA KARYAWAN DAN PROMOSI JABATAN DENGAN METODE GAUGING ABSENCE OF PREREQUISITES (GAP) PADA PT. ESENSI INDONESIA
}

\author{
${ }^{1}$ Puji Kurniati*, ${ }^{2}$ Sri Lestari, \\ Sistem Informasi, STIKOM Cipta Karya Informatika \\ Jl. Raden Inten II No. 8A, Duren Sawit, Jakarta Timur, Indonesia \\ Kurnianugroho10@gmail.Com Sri.lestari1203@gmail.Com
}

Received: 2021-08-26, Revised: 2021-08-30, Accepted: 2021-09-02

\section{Abstrak}

Sistem penilaian kinerja karyawan dan promosi jabatan merupakan hal penting dalam sebuah perusahaan, dan dalam mengetahui perkembangan kinerja karyawan perusahaan. Penilaian kinerja karyawan yang dilakukan secara manual menjadi permasalahan tersendiri bagi sebuah perusahaan. Hal ini juga dialami pada PT. Esensi Indonesia, dimana penilaian kinerja karyawan masih menggunakan cara manual. Penilaian dilakukan oleh team leader untuk mengetahui karyawan yang berpotensi bagus untuk dipromosikan kejenjang karier berikutnya, dan kemudian hasil penilaian diserahkan kepada superivor dan berlanjut ke manager dan terakhir ke HRD dalam bentuk yang masih kertas.Hal ini yang menyebabkan data dan penilaian menjadi lebih merepotkan karena harus ditulis dan dihitung secara manual dan memperlukan waktu yang panjang.. Proses penilaian kinerja karyawan dan promosi jabtan pada PT. Esensi Indonesia dilakukan setiap setahun sekali dan berdasarkan beberapa kriteria yang akan dinilai belum menggunakan metode yang khusus sehinggamasih terdapat kesalahandalam perhitungan.

Penelitian ini dilakukan bertujuan untuk menerapkan metde gauging absence of prerequistes (GAP) dalam proses penilaian kinerja karyawan dan promosi jabatan pada PT. Esensi Indonesia. Dengan metode GAP ini dapat membantu menilai seberapa besarnya jarak antara kinerja aktual dengan standar nilai kinerja yang diharapkan dan untuk mengetahui kebutuhan peningkatan kinerja yang diperlukan.

\section{Kata Kunci : Penilaian kinerja, Promosi Jabatan, GAP \\ Abstract}

The employee performance appraisal system and promotion are important things in a company, and in knowing the development of the company's employee performance. Employee performance appraisal that is done manually is a problem for a company. This is also experienced at PT. Esensi Indonesia, where employee performance appraisal is still using the manual method. The assessment is carried out by the team leader to identify employees who have good potential to be promoted to the next career level, and then the results of the assessment are submitted to the supervisor and continue to the manager and finally to HRD in paper form. written and calculated manually and takes a long time. The process of evaluating employee performance and promotion to positions at PT. The essence of Indonesia is carried out once a year and based on several criteria that will be assessed, it has not used a special method so that there are still errors in the calculations.

This research was conducted with the aim of applying the gauging absence of prerequistes (GAP) method in the process of evaluating employee performance and promotion at PT. Indonesian essence. With this GAP method, it can help assess how big the gap between the actual performance 
DOI: $10.52362 /$ jmijayakarta.v1i4.572

and the standard of the expected performance value is and to find out the need for the required performance improvement.

Keywords: Performance appraisal, Promotion, GAP

Keywords: Maximum of 5 keywords, separate with commas, must specific, avoid abbreviation (according to the scope of article). [Times New Roman font 11, single space].

\section{Pendahuluan (or Introduction)}

Di era Globalisasi seperti sekarang ini kebutuhan akan teknologi dan bisnis dalam kehidupan tidak dapat dipisahkan lagi. Hampir semua aspek kehidupan kita tidak terlepas dari teknologi. Orangorang akan menggunakan teknologi untuk memudahkan mereka dalam melakukan aktivitasnya. Teknologi yang digunakan dapat menunjang keberhasilan untuk bersaing daengan perusahaan lain.

Teknologi dalam rencana bisnis perusahaan digunakan untuk berbagai hal seerti,penyimpanan berkas, penyimpanan barang penjualan hingga pemesanan produk pada perusahaan. Salahsatu perusaaan yang sedang mengembangkan bisnisnya yaitu PT. Esensi Indonesia.PT. Esensi Indonesia adalah perusahan yang bergerak dibidang Facility Service.

Perusaaan Esensi menawarkan berbagai fasilitas diantara lain, Cleaning Service, Facade Cleaning, Pest Contro Management, Gardening/Lanscape dan Office Support. Namun terdapat kendala didalam internal perusahaan yaitu tentang penilaian kinerja karyaan dan kenaikan jabatan, dimana penilaian tersebut masih dilakukan secara manual, dengan pengisian form yang masih menggunakan kertas. Penilaian dilakukan oleh Supervisor dan Manager terhadap karyawan dan kemudian hasil dari penilaian tersebut diserahkan ke pukah HRD, kemudian dilakukann penilaian dengan kriteria, absensi, perilaku,kecerdasan dan penampilan. Untuk itu diperlukan cara yang efektif agar tidak salah dalam menentukan penilaian dan dari itu dibutuhkan sebuah sistem pendukung keputusan yang dapat menganalisa antara profil karyawan sesuai dengan profil jabatan yang ada.

Berdasarkan permasalahan diatas penelitian ini menerapkan metode Gauging Absence of Prerequistes $(G A P)$ kaitannya metode tersebut adalah dapat mengevaluasi kinerja karyawan dan menilai seberapa besarnya jarak antara kinerja aktual dengan standar nilai kinerja yang diharapkan.

\section{Tinjauan Literatur (or Literature Review)}

Penelitian terdahulu dilakukan oleh Munawir dan Ardiansyah yang berjudul “ Decision Support System Pemilihan Karyawan Berprestasi Dengan Pendekatan Analisa Gap Profile Matching Di Kantor Perwakilan Bank Indonesia Provinsi Aceh" Penelitian ini membangun sebuah sistem pendukung keputusan dalam pemilihan karyawan berprestasi dikantor Perwakilan Bank Indonesia Provinsi Aceh yang diharapkan dapat membantu pra pembuat keputusan dalam memutuskan alternatif-alternatif terbaik dalam pemilihan karyawan berprestasi.

Penelitian terdahulu dilakukan oleh Brian Aif Maulana dkk yang berjudul "Sistem Pendukung Keputusan pemilihan BEST AGENT dengan Metode Profile Matching (GAP)" Penelitian ini bertujuan untuk merancang sebuah sistem dan model dalam pengambilan keputusan untuk menentukan BEST AGENT menggunakan metode Profile Matching merupakan sebuah aplikasi yang dirancag untuk memberikan sebuah alternatif keputusan yang akurat didasarkan pada data terkini dan dapat dipertanggung jawabkan, hal ini diharapkan dapat meningkatkan kualitas kinerja dan harapan besarnya adalah terbangunnya peningkatan kinerja yang baik sehingga meningkatkan kualitas SDM.

Penelitian terdahulu dilakukan oleh Yohanis Malelak yang berjudul "Sistem Pendukung Keputusan Ususlan Kenaikan Pangkat dan Golongan dengan Menggunakan Metode GAP Pada Dinas Kebudayaan dan Pariwisata Provinsi Nusa Tenggara Timur" Penelitian ini dilakukan untuk 
DOI: $10.52362 /$ jmijayakarta.v1i4.572

menetukan calon pegawai negeri sipil yang akan diusulkan kenaikan mendata calon pegawai beserta kinerja kerja selama masa aktif yang beserta kriteria-kriteria atau aturan persyaratan kenaikan pangkat pegawai.

Penelitian terdahulu dilakukan oleh Adiyanto dan Devi Sahara yang berjudul "Penerapan Metode GAP pada Sistem Pendukung Keputusan kenaikan Jabatan Di PT. KMK Global Sport" Penelitian ini bertujuan pada proses kenaikan jabatan sering mengalami kesulitan karena pengajuan calon kandidat yang bisa menempati jabatan tersebut dengan cara pencocokan profil karyawan dan profil jabatan kurang terdefiniis dengan baik. Untuk meminimumkan beberapa kendala tersebut diperlukan suatu sistem pendukung keputusan yang bisa menganalisa beberapa karyawan yang sesuai dengan profil jabatan yang ada.

Penelitian terdahalu dilakukan oleh Merry Agustinayang berjudul "Implementasi Metode Gauging Absence Of Prerequistes (GAP) Pada Sistem Penilaian Kinerja (Performance Appaisal) Karyawan PT. XYZ" Dengan metode GAP ini dapat menilai dapat seberapa besarnya jarak antarakinerja aktual dan dengan standar nilai kinerja yang diharapkan dan untuk mengetahui kebutuan peningkatan kinerja yang diperlukan.

Penelitian terdahulu dilakukan oleh Sofyan Huda dkk yang berjudul "Sistem Pendukung Keputusan Kelayakan Produk Contoh Pada PT. Roi Surya Prima Farma (Studi perbandingan Metode SAW dan GAP Analisis)" Penelitian ini bertujuan untuk membangun sebuah sistem penunjang keputusan yang mampu memberikan penilaian dalam kelayakan pengiriman sampel produk terhadap dokter dengan menggunakan metode Profile Matching (Gap Anlysis) dan simple Additive Weighting (SAW) berdasarkan kriteria-kriteria penilaian yang telah ditentukan sebagai acuan. Kemudian output dari kedua metode tersebut akan dibandingkan dengan data hasil yang nyata.

Penelitian terdahulu dilakukan oleh Yely Yosiana dkk yang berjudul "Implementasi Metode Analisis GAP dan Profile Matching Untuk Kelayakan Calon Debitur di Koperasi Simpan Pinjam (KP) Kopdit Solidaritas Santa Maria Assumpta" Penelitian ini bertujuan untuk mengetahui layak atau tidaknya pemebrian kredit kepada debitur, ksp Kopdit solidaritas telah menetapkan standar kebijakan dalam pemberian kredit untuk menerima atau menolak resiko kredit macet. Penilaian calon debitr yang memenuhi syarat, dan mampu melunasi kredit, modal yang dimiliki, jaminan yang dimiliki dan kondisi sosial ekonomi. Dalam penelitian dilakukan perancangan dan pembuatan aplikasi sistem pendukung keputusandengan menggunakan metode profile matching untuk menilai kelayakan calon debitur.

Penelitian terdahulu dilakukan oleh Apriana Panca Kartikasari dkk yang berjudul "Sistem pendukung Keputusan Untuk Penilaian Kinerja Pegawai dengan Metode GAP (Profile Matching) Berbasis Web Studi kasus : Batik Baenang Ratu" Penelitian membahas bahwasanya sumber daya manusia (SDM) merupakan salah satu subyek perusahaan yang harus dikelola dengan baik untuk meningkatkan kebersihan dari perusahaan.Sistem pendukung keputusan penilaian kinerja karyawan dengan metode GAP (Profile Matching) sangat tepat diterapkan di bAtik Benang Ratu agar penilaian bersifat objektif dan transfaran berdaasarkan standar yang dimiliki oleh perusahaan.

Penelitian terdahulu dilakukan oleh Andrian Setiawan dkk yang berjudul "Implementasi Metode Analisis GAP dan Profile Matching untuk Seleksi Penerimaan Penyiar Radio (Studi Kasus PT Radio Swaraunib FM)" Penelitian ini bertujuan untuk menyeleksi penyiar yang baik pada saat periode penerimaan, terdapat banyak pelamar dimana akan dipilih sejumlah calon penyiar berkualitas yang sesuai dengan kriteria-kriteria yang dibutuhkan oleh radio tersebut.

Penelitian terdahulu yang dilakukan oleh Riska Shoumil Ilham dkk yang berjudul "Penilaian Kinerja Karyawan dengan Metode AHP dan Rating Scale" Penelitian ini dilakukan untuk menciptakan sumber manusia yang handal, dan dibutuhkan pengolahan SDM yang baik didalam sebuah perusahan atau organisasi. Pengolahan SDM dapat dilakukan melaluui penilaiankinerja karyawan atau performance appraisal.

Penelitian terdahulu dilakukan oleh Wahyu Maulana yang berjudul "Pengaruh Promosi jabatan, Kompensasi dan Stres Kerja Terhadap Kinerja Karyawan PT. TEMA (Trijaya Excel Madura) melalui 
DOI: $10.52362 / j m i j a y a k a r t a . v 1 i 4.572$

Kepuasan Kinerja" Penelitian ini bahwa kepuasan kerja dalam perusahaan ini dipengaruhi oleh adanya promosi jabatan yang merata dan terbuka, kompensasi yang memadai serta pengolahan stres kerja yang baik. Untuk meningkatkan kinerja para karyawan lebih optimal,faktor perolehan kompensasi yang sesuai pekerjaan dan guna meraih kesempatan untuk promosi jabatan ke level yang lebih meningkat memiliki pengaruh yang signifikan dalam perusahan ini.

Penelitian terdahulu dilakukan oeh subhan Akbar Diwanda dkk yang berjudul "Sistem Pendukung Keputusan Penilaian Kinerja Karyawan Menggunakan Metode Multifactor Evalution Proces Pada PT. Konsul Wilayah Sulawesi Tenggara" Penelitian ini menentukan penilaian kinerja karyawan berdasarkan beberapa faktor penilaian, faktor penilaian tersebut terdiri dari kecakapan, watak dan tingkah laku, loyalitas. Demi efektifitas kerja dalam penilaian kinerja maka pengambilan keputusan yang tepat sangat diperlukan, oleh karena itu dibuatkan perangkat lunak yang dapat mengambil sebuah keputusan untuk melaporkan penilaian kinerja karyawan.

Penelitian terdahulu dilakukan oleh Bixon Natanael dkk yang berjudul "Analisis dan Perancangan Sistem Informasi Penelitian Kinerja Karyawan Pada PT. BPR Universal Sentosa" Penelitian ini bertujuan untuk menganalisa dan merancang sistem informasi penilaian kinerja karyawan dengan menerapkan sistem informasi penilaian kinerja karyawan dengan menerapkan sistem iformasi penilaian kinerja berbasis web. Kerangka penelitian terdiri dari studi literatur,pengumpulan data, analisis data,pengembangan sistem dan pembuatan laporan.

Penelitian terdahulu dilakukan oleh Kevin Tangkuman dkk yang berjudul "Penilaian Kinerja, Reward dan Punishment Terhadap Kinerja Karyawan Pada PT. Pertamina (Persero) Cabang Pemasaran Suluttenggo"Penelitian ini bertujuan untuk mengetahui pengaruh secara simultan maupun persial penilaian kinerja, reward dan punishment terhadap kinerja karyawan. Penelitian in menggunakan metode explanotory research dengan pendekatan kuantitatif dan sampel sebanyak 50 karyawan PT. Pertamina (Perseroa) Manado.

\section{Metode Penelitian (or Research Method)}

\subsection{Metode Gauging Absece Of Prerequistes (GAP)}

Metode ini dapat digunakan untuk membantu menganalisis dan mempersempit jarak. Pemetaan Gap kompetensi untuk sistem pendukung keputusan penilaian karyawan dan promosi jabatan agar tidak terjadi jarak antara satu karyawan dengan karyawan yang lain. Menurut Kusrini (2007) metode Gauging Absence Of Prerequistes Gap disini adalah beda antara profil jabatan dengan profil karyawan atau dapat ditunjuk pada rumus :

GAP $=$ Profil Karyawan - Profil Jabatan

Sedangkan untuk pengumpulan gap-gap yang terjadi itu sendiri pada setiap aspeknya mempunyai perhitungan Gap yaitu :

\section{Pemetaan Gap Kompetensi}

Pada tahapini setiap profit karyawan yang mengacu pada kriteria-kriteria yang menentukan kinerja akan diproses dengan cara dikurangkan dengan standar nilai kriteria tersebut.

2. Pembobotan

Setelah doperoleh gap masing-masing karyawan, profit karyawan diberikan bobot untuk dinilai dengan patokan table bobot nilai gap.

3. Perhitungan dan Pengelompokan Core dan Secondary Factor

Setelah menetukan nilai bobot gap pada setiap kriteria yang dinilai,maka kriteria tersebut dibagikan menjadi dua kelompok, yaitu Care Factor dan Secondary Factor. Care Factor merupakan kriteria yang dominan yang diperkirakan dapat menghasilkan kinerja optimal, sedangkan Secondary Factor ialah kriteria aspek yang ada pada Core Factor, adapun perhitugannya adalah dengan rumus berikut : 
DOI: 10.52362/jmijayakarta.v1i4.572

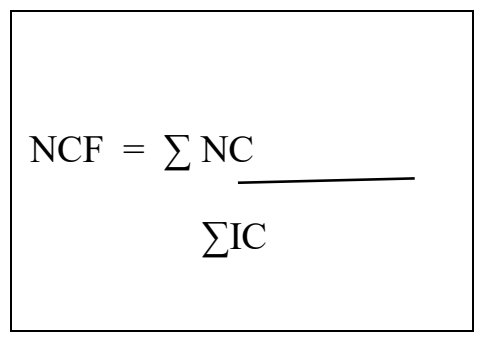

Keterangan :

$\mathrm{NCF}$ : Nilai rata-rata Care Factor

NC : Jumlah total nilai Care Factor

IC : Jumlah item Care Factor

Sedangkann untuk rumus Secondary Factor adalah sebagai berikut :

$$
\mathrm{NSF}=\frac{\sum \mathrm{NS}}{\sum \mathrm{IS}}
$$

Keterangan :

NSF : Nilai rata-rata Care Factor

NS : Jumlah total nilai Secondary Factor

IS : Jumlah item Secondari Factor

4. Perhitungan Nilai Total

Hasil akhir dari proses perhitungan adalah ranking kandidat yanng diajukan untuk mengisi suatu jabatn, pennetu ranking berpatokan pada perhitungan tertentu. Penentuan tersebut ditunjukan dengan rumus sebagaiberikut :

$$
\mathrm{N}=(\mathrm{X}) \% \mathrm{NCF}+(\mathrm{X}) \% \mathrm{NSF}
$$

Keterangan :

NCF : Nilai rata-rata Core Factor

NSF : Nilai rata-rata Secondari Factor

$\mathrm{N} \quad$ : Nilai total dari aspek

(X) $\%$ : Nilia persen yang diinput

5. Perhitungan Penentuan Ranking

Hasil akhir dari proses perhitungan adalah ranking kandidat yang diajukan untuk mengisi suatu jabatan, penetuan ranking berpatokan pada perhitungan tertentu. Penetuan tersebut ditunjukan dengan rumus sebagai berikut :

$$
\text { Ranking }=\mathbf{X}(\%) \mathbf{N}
$$


DOI: $10.52362 / j m i j a y a k a r t a . v 1 i 4.572$

Keterangan :

$\mathrm{N} \quad$ : Nilai rata-rata intelektual

$(\mathrm{X}) \% \quad$ : Nilai persen yang diinput

Setelah setiap kandidat mendapatkan hasil, maka bisa ditentukan peringkat ranking dari kandidat berdasarkan pada besarya nilai hasil akhir sehingga semakin besar pula nilai kinerja karyawan tersebut begitu pula sebaliknya.

3.2 Use Case diagram

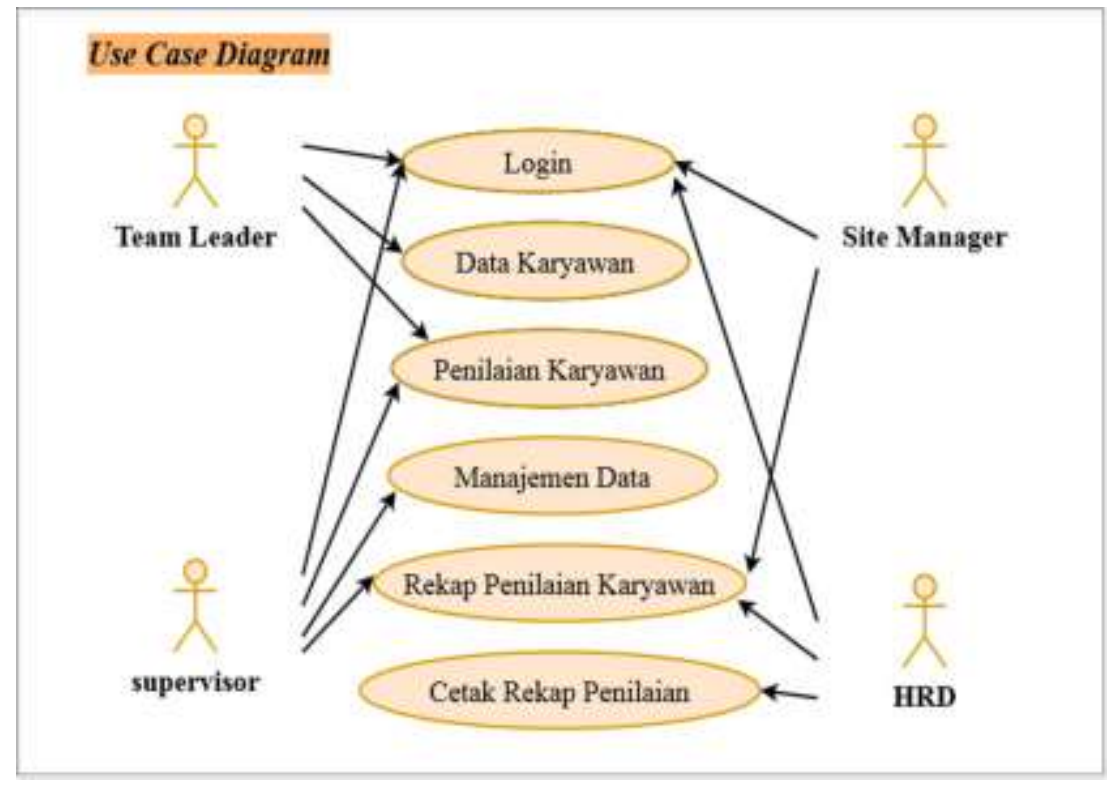

Gambar 1. Use Case Diagram

Dimana Team Leader mendata karyawan baru dan melakukann penilaian, setelah itu hasil penilaian tersebut diserahkan ke atasannya yaitu Supervisor untuk dicek ulang hasil penilaian tersebut. Jika dalam pengecekan tidak ada yang dirubah, selanjutnya diserahkan ke Site Manager akan tetapi jika dalam pengecekan ada yang tidak sesuaidikembalikan ke bagian Team Leader untuk diperbaiki. Dibagian Site Manager hasil penilaian dicek lagi dan dilanjutkan ke bagian HRD, begitu dengan di Site Manager jika dalam pengecekan ada yang tidak sesuai dikembalikan ke bagian Supervisor untuk diperbaiki. Di bagian HRD dilakukan penilaian dan hasilnya akan dicetak dalam rekap penialian dan akan diumumkan hasil dari penialian tersebut.

\section{Hasil dan Pembahasan (or Results and Analysis)}

\subsection{Analisa GAP}

Dalam melakukan penilaian kinerja karyawan dan promosi jabatan pada PT. Esensi Indonesia ada setidaknya 10 Kriteria yang harus dinilai antara lain :

Penampilan, Pelayanan, Sopan Santun, Kwalitas Kerja, Inisiatif, Loyalitas, Profesional dalam Kerja, Kepimpinan, Kerjasama Team, dan Kejujuran. Sebelum memulai untuk perhitugan maka ditentukan dulu konversi untuk nilainya.

\section{Tabel 1. Nilai Konversi}


DOI: $10.52362 / j m i j a y a k a r t a . v 1 i 4.572$

\begin{tabular}{|l|l|l|}
\hline Sangat Baik & $100-91$ & $=5$ \\
\hline Baik & $90-76$ & $=4$ \\
\hline Cukup & $75-61$ & $=3$ \\
\hline Kurang Baik & $60-51$ & $=2$ \\
\hline Buruk & 50 kebawah & $=1$ \\
\hline
\end{tabular}

1. Pemetaan GAP Kompetensi

Yang dimaksud disini adalah beda antara profil karyawan dengan profil kinerja atau standar nilai sikap kinerja yang didapat dengan menggunakan rumus berikut

\section{Gap $=$ Profil Karyawan - Profil Kinerja $($ standar nilai kriteria $)$}

Dimana profil karyawan merupakan penilaian karyawan untuk setiap kriteria, sedangkan profil kinerja atau standar nilai kinerja adalah standar yang ditetapkan oleh manajemen perusahaan untuk setiap kriteria yang dalam hal ini pastinya pada standar yang sangat baik.

a. Kriteria Sikap Kerja Karyawan

Untuk penilaian sikap kerja terdiri dari 5 item Sub Kriteria yang akan dinilai yaitu :

Pelayanan (SK1), Penampilan (SK2), Sopan Santun (SK3), Kwalitas Kerja (SK4), Profesional dalam Bekerja (SK5). Berikut tabel yang menunjukan GAP Karyawan untuk kriteria Sikap Kerja.

Tabel 2. Penilaian Karyawan Sikap Kerja

\begin{tabular}{|c|c|c|c|c|c|c|}
\hline \multirow{2}{*}{ No } & \multirow{2}{*}{ NIK } & \multicolumn{5}{|c|}{ Sub Kriteria } \\
\hline & & SK1 & SK2 & SK3 & SK4 & SK5 \\
\hline 1 & 1002 & 4 & 3 & 4 & 4 & 4 \\
\hline 2 & 1010 & 4 & 4 & 4 & 3 & 4 \\
\hline 3 & 1022 & 4 & 3 & 4 & 4 & 4 \\
\hline 4 & 1017 & 3 & 2 & 3 & 3 & 3 \\
\hline 5 & 1024 & 4 & 3 & 3 & 3 & 4 \\
\hline 6 & 1003 & 4 & 4 & 4 & 4 & 3 \\
\hline 7 & 1008 & 4 & 4 & 4 & 4 & 4 \\
\hline 8 & 1005 & 4 & 4 & 4 & 4 & 4 \\
\hline \multicolumn{2}{|c|}{ Profil Kinerja } & 5 & 5 & 5 & 5 & 5 \\
\hline \multicolumn{7}{|c|}{ GAP } \\
\hline 1 & 1002 & -1 & -2 & -1 & -1 & -1 \\
\hline 2 & 1010 & -1 & -1 & -1 & -2 & -1 \\
\hline 3 & 1022 & -1 & -2 & -1 & -1 & -1 \\
\hline 4 & 1017 & -2 & -3 & -2 & -2 & -2 \\
\hline 5 & 1024 & -1 & -2 & -2 & -2 & -1 \\
\hline 6 & 1003 & -1 & -1 & -1 & -1 & -2 \\
\hline 7 & 1008 & -1 & -1 & -1 & -1 & -1 \\
\hline 8 & 1005 & -1 & -1 & -1 & -1 & -1 \\
\hline
\end{tabular}

b. Kriteria Perilaku Karyawan

Untuk penilaian kriteria kriteria perilaku karyawan terdiri dari 5 item sub kriteriayang dimulai dari : inisiatif (PK1), Loyalitas (PK2), Kepimpinan (PK3), 
Kerjasama Team (PK4), Kejujuran (PK5). Berikut tabel yang menunjukan GAP karyawan untuk kriteria Perilaku Karyawan.

Tabel 3. Penilaian karyawan Perilaku Kerja

\begin{tabular}{|c|c|c|c|c|c|c|}
\hline \multirow{2}{*}{ No } & \multirow{2}{*}{ NIK } & \multicolumn{5}{|c|}{ Sub Kriteria } \\
\hline & & $\overline{\text { PK1 }}$ & PK2 & PK3 & PK4 & PK5 \\
\hline 1 & 1002 & 4 & 4 & 4 & 4 & 5 \\
\hline 2 & 1010 & 4 & 3 & 4 & 4 & 5 \\
\hline 3 & 1022 & 4 & 4 & 4 & 4 & 5 \\
\hline 4 & 1017 & 3 & 4 & 3 & 3 & 4 \\
\hline 5 & 1024 & 4 & 3 & 4 & 4 & 5 \\
\hline 6 & 1003 & 4 & 3 & 4 & 4 & 5 \\
\hline 7 & 1008 & 4 & 4 & 4 & 4 & 5 \\
\hline 8 & 1005 & 4 & 4 & 3 & 4 & 5 \\
\hline \multicolumn{2}{|c|}{ Profil Kinerja } & 5 & 5 & 5 & 5 & 5 \\
\hline \multicolumn{7}{|c|}{ GAP } \\
\hline 1 & 1002 & -1 & -1 & -1 & -1 & 0 \\
\hline 2 & 1010 & -1 & -2 & -1 & -1 & 0 \\
\hline 3 & 1022 & -1 & -1 & -1 & -1 & 0 \\
\hline 4 & 1017 & -2 & -1 & -2 & -2 & -1 \\
\hline 5 & 1024 & -1 & -2 & -1 & -1 & 0 \\
\hline 6 & 1003 & -1 & -2 & -1 & -1 & 0 \\
\hline 7 & 1008 & -1 & -1 & -1 & -1 & 0 \\
\hline 8 & 1005 & -1 & -1 & -2 & -1 & 0 \\
\hline
\end{tabular}

c. Kriteria Presensi Karyawan

Kriteria presensi atau kehadiran karyawan merupakan kehadiran karyawan PT. Esensi Indonesia dalam bekerja dan mengikuti jam kerja yang telah ditentukan sesuai dengan schedule yang dibuat oleh atasan. Proses absen yang dilakukan masih menggunakan manual dengan menulis dikertas dan dihitung menggunakan Ms. Excel. Berikut ini GAP kriteria presensi karyawan :

Tabel 4. Presentasi Karyawan

\begin{tabular}{|c|c|c|}
\hline No & NIK & Presensi \\
\hline 1 & 1002 & 4 \\
\hline 2 & 1010 & 4 \\
\hline 3 & 1022 & 5 \\
\hline 4 & 1017 & 4 \\
\hline 5 & 1024 & 1 \\
\hline 6 & 1003 & 4 \\
\hline 7 & 1008 & 5 \\
\hline 8 & 1005 & 2 \\
\hline Profil Kinerja & & $\mathbf{5}$ \\
\hline \multicolumn{2}{|c|}{} & GAP \\
\hline 1 & 1002 & -1 \\
\hline 2 & 1010 & -1 \\
\hline
\end{tabular}


DOI: $10.52362 / j m i j a y a k a r t a . v 1 i 4.572$

\begin{tabular}{|c|c|c|}
\hline 3 & 1022 & 0 \\
\hline 4 & 1017 & -1 \\
\hline 5 & 1024 & -4 \\
\hline 6 & 1003 & -1 \\
\hline 7 & 1008 & 0 \\
\hline 8 & 1005 & -3 \\
\hline
\end{tabular}

2. Bobot Niali

Setelah diperoleh nilai gap,langkah selanjutnya diberikan bobot untuk masing-masing nilai gap tersebut berdasarkan tabel nilai bobot gap berikut :

Tabel 5. Bobot Nilai GAP

\begin{tabular}{|l|l|l|}
\hline $\begin{array}{c}\text { Selisih } \\
\text { GAP }\end{array}$ & Bobot Nilai & \multicolumn{1}{|c|}{ Keterangan } \\
\hline 0 & 5 & $\begin{array}{l}\text { Tidak ada selisih (kompetensi sesuai dengan yang } \\
\text { dibutuhkan) }\end{array}$ \\
\hline 1 & 4,5 & Kompetensi individu kelebihan 1 tingkat/level \\
\hline-1 & 4 & Kompetensi individu kekurangan 1 tingkat/level \\
\hline 2 & 3,5 & Kompetensi individu kelebihan 2 tingkat/level \\
\hline-2 & 3 & Kompetensi individu kekurangan2 tingkat/level \\
\hline 3 & 2,5 & Kompetensi individu kelebihan 3 tingkat/level \\
\hline-3 & 2 & Kompetensi individu kekurangan 3 tingkat/level \\
\hline 4 & 1,5 & Kompetensi individu kelebihan 4 tingkat/level \\
\hline-4 & 1 & Kompetensi individu kekurangan 4 tingkat/level \\
\hline
\end{tabular}

Dari tabel nilai bobot diatas maka dapat ditentukan hasil bobot nilai gap dari masing-masing kriteria. Hasil dari nilai bobot setiap kriteria penilaian dapat ditunjukan pada tabel berikut ini

Tabel 6. Hasil Pemetaan GAP Kompetensi

\begin{tabular}{|l|c|l|c|c|c|c|c|c|}
\hline \multirow{2}{*}{ No } & NIK & & SK1 & SK2 & SK3 & SK4 & SK5 & Presensi \\
\hline $\mathbf{1}$ & 1002 & Gap & -1 & -2 & -1 & -1 & -1 & -1 \\
\hline & & Bobot & $\mathbf{4}$ & 3 & $\mathbf{4}$ & $\mathbf{4}$ & $\mathbf{4}$ & $\mathbf{4}$ \\
\hline $\mathbf{2}$ & 1010 & Gap & -1 & -1 & -1 & -2 & -1 & -1 \\
\hline & & Bobot & $\mathbf{4}$ & $\mathbf{4}$ & $\mathbf{4}$ & 3 & $\mathbf{4}$ & $\mathbf{4}$ \\
\hline $\mathbf{3}$ & 1022 & Gap & -1 & -2 & -1 & -1 & -1 & $\mathbf{0}$ \\
\hline & & Bobot & $\mathbf{4}$ & 3 & $\mathbf{4}$ & $\mathbf{4}$ & $\mathbf{4}$ & $\mathbf{5}$ \\
\hline $\mathbf{4}$ & 1017 & Gap & -2 & -3 & -2 & -2 & -2 & -1 \\
\hline & & Bobot & $\mathbf{3}$ & $\mathbf{2}$ & $\mathbf{3}$ & $\mathbf{3}$ & $\mathbf{3}$ & $\mathbf{4}$ \\
\hline $\mathbf{5}$ & 1024 & Gap & -1 & -2 & -2 & -2 & -1 & -4 \\
\hline & & Bobot & $\mathbf{4}$ & $\mathbf{3}$ & $\mathbf{3}$ & $\mathbf{3}$ & $\mathbf{4}$ & $\mathbf{1}$ \\
\hline
\end{tabular}


DOI: $10.52362 / j m i j a y a k a r t a . v 1 i 4.572$

\begin{tabular}{|l|c|l|c|c|c|c|c|c|}
\hline $\mathbf{6}$ & 1003 & Gap & -1 & -1 & -1 & -1 & -2 & -1 \\
\hline $\mathbf{7}$ & & Bobot & $\mathbf{4}$ & $\mathbf{4}$ & $\mathbf{4}$ & $\mathbf{4}$ & $\mathbf{3}$ & $\mathbf{4}$ \\
\hline & & Gap & -1 & -1 & -1 & -1 & -1 & $\mathbf{0}$ \\
\hline $\mathbf{8}$ & 1005 & Gobot & $\mathbf{4}$ & $\mathbf{4}$ & $\mathbf{4}$ & $\mathbf{4}$ & $\mathbf{4}$ & $\mathbf{5}$ \\
\hline & & Bobot & -1 & -1 & -1 & -1 & -1 & -3 \\
\hline & & & $\mathbf{4}$ & $\mathbf{4}$ & $\mathbf{4}$ & $\mathbf{4}$ & $\mathbf{4}$ & $\mathbf{2}$ \\
\hline $\mathbf{1}$ & 1002 & Gap & PK 2 & $\mathrm{PK} 3$ & $\mathrm{PK} 4$ & $\mathrm{PK} 5$ & \\
\hline & & Bobot & $\mathbf{4}$ & -1 & -1 & -1 & 0 & \\
\hline $\mathbf{2}$ & 1010 & Gap & -1 & -2 & -1 & -1 & 0 & \\
\hline & & Bobot & $\mathbf{4}$ & $\mathbf{3}$ & $\mathbf{4}$ & $\mathbf{4}$ & $\mathbf{5}$ & \\
\hline $\mathbf{3}$ & 1022 & Gap & -1 & -1 & -1 & -1 & 0 & \\
\hline & & Bobot & $\mathbf{4}$ & $\mathbf{4}$ & $\mathbf{4}$ & $\mathbf{4}$ & $\mathbf{5}$ & \\
\hline $\mathbf{4}$ & 1017 & Gap & -2 & -1 & -2 & -2 & -1 & \\
\hline & & Bobot & $\mathbf{3}$ & $\mathbf{4}$ & $\mathbf{3}$ & $\mathbf{3}$ & $\mathbf{4}$ & \\
\hline $\mathbf{5}$ & 1024 & Gap & -1 & -2 & -1 & -1 & 0 & \\
\hline & & Bobot & $\mathbf{4}$ & $\mathbf{3}$ & $\mathbf{4}$ & $\mathbf{4}$ & $\mathbf{5}$ & \\
\hline $\mathbf{6}$ & 1003 & Gap & -1 & -2 & -1 & -1 & 0 & \\
\hline & & Bobot & $\mathbf{4}$ & $\mathbf{3}$ & $\mathbf{4}$ & $\mathbf{4}$ & $\mathbf{5}$ & \\
\hline $\mathbf{7}$ & 1008 & Gap & -1 & -1 & -1 & -1 & 0 & \\
\hline & & Bobot & $\mathbf{4}$ & $\mathbf{4}$ & $\mathbf{4}$ & $\mathbf{4}$ & $\mathbf{5}$ & \\
\hline $\mathbf{8}$ & 1005 & Gap & -1 & -1 & -2 & -1 & 0 & \\
\hline & & Bobot & $\mathbf{4}$ & $\mathbf{4}$ & $\mathbf{3}$ & $\mathbf{4}$ & $\mathbf{5}$ & \\
\hline
\end{tabular}

3. Perhitungan dan Pengelompokan Care Factor dan Secondary Factor

Setelah menentukan nilai bobot gap, kemudian setiap kriteria penilaian dikelompokan menjadi 2 kelompok yaitu care factor dan secondary facto.

Berikut contoh perhitungan penilaian untuk menentukan karyawan yang terbaik dan dapat dipromosikan dengan NIK karyawan 1002.

a. Kriteria Sikap Kerja

1) Care Factor $=\mathrm{SK} 1, \mathrm{SK} 4$, dan $\mathrm{SK} 5$

$\mathrm{NCF}=\Sigma \mathrm{NC}=4+4+4=12$

$$
\overline{\Sigma \mathrm{IC}} \quad 3=4
$$

Jadi untuk karyawan dengan NIK 1003 nilai Care Factornya sebesar 4 untuk kriteria sikap kerja.

2) Secondary Factor $=\mathrm{SK} 2$, dan SK3

$\mathrm{NSF}=\Sigma \mathrm{NS}=3+4=7$

$$
\begin{array}{ll}
\Sigma \mathrm{I} 2 & =3.5
\end{array}
$$


Jadi untuk karyawan dengan NIK 1003 nilai Secondary Factor sebesar 3.5 untuk kriteria sikap kerja.

b. Kriteria Perilaku Kerja

1) Care Factor $=\mathrm{PK} 3$, PK4, dan PK5

$$
\mathrm{NCF}=\Sigma \mathrm{NC}=4+4+5=13
$$

Jadi untuk karyawan dengan NIK 1003 nilai Care Factor sebesar 4.4 untuk kriteria perilaku kerja.

2) Secondary Factor $=$ PK1 dan PK

$$
\mathrm{NSF}=\underset{\Sigma \mathrm{NS}=4+4=8}{\Sigma} \quad=4
$$

Jadi untuk karyaan dengan NIK 1003 nilai Secondary Factor sebesar 4 untuk kriteria perilaku kerja.

4. Perhitungan Nilai Total

Dari hasil perhitungan dari tiap item diatas kemudian dihitung nilai total berdasarkan presentase dari Care Factor dan Secondary Factor yang diperkirakan berpengaruh terhadap kinerja tiap-tiap profil. Berikut ini sebagai contoh perhitungan nilia dari NIK 1002 :

\section{a. Kriteria Sikap Kerja}

$$
\mathrm{N}=60 \% \mathrm{NCF}+40 \% \mathrm{NSF}
$$

$\mathrm{NSK}=(60 \% \times 4)+(40 \% \times 3.5)=3.8$

Jadi untuk karyawan NIK 1003 memiliki nilai total sebesar 3.8 pada kriteria sikap kerja.

b. Kriteria Perilaku Kerja

$$
\mathrm{N}=60 \% \mathrm{NCF}+40 \mathrm{NSF}
$$

$\mathrm{NPK}=(60 \% \times 4.4)+(40 \% \times 4)=4.24$

Jadi untuk karyawan NIK 1003 memiliki nilai total sebesar 4.24 pada kriteria perilaku kerja.

5. Perhitungan Penentuan Ranking

Hasil akhir dari proses gap adalah ranking dari kandidat yang diajukan untuk mengisi suatu jabatan tertentu,sebagai contoh dari rumus untuk perhitungan ranking sebelumnya. Maka hasil akhir dari karyawan dengan NIK 1002 sebagai berikut :

$$
\begin{aligned}
& \text { Ranking }=50 \% \text { NSK }+50 \% \text { NPK } \\
& \begin{aligned}
\text { Ranking } & =(50 \% \times 3.8)+(50 \% \times 4.24) \\
& =1.9+2.12 \\
& =4.02
\end{aligned}
\end{aligned}
$$


DOI: $10.52362 /$ jmijayakarta.v1i4.572

Setelah didapatkan hasil akhir untuk ranking, maka dapat ditentukan peringkat atau ranking tiap kandidat berdasarkan pada semakin besar nilai hasil akhir maka semakin besar kesempatan untuk menduduki jabtan yang ada, dan begitu sebaliknya.

\section{$5 \quad$ Kesimpulan (or Conclusion)}

Berdasarkan penelitian yang dilkaukan dapat di kesimpulkan dari metode GAP tersebut, Sistem Pengambilan Keputusan Penilian Kinerja Karyawan dan Promosi Jabatan pada PT.Esensi Indonesia adalah ;

1. Perhitungan nilai kinerja karyawan yang dilakukan melalaui tahapan dan langkah-langkah yang jelas.

2. Hasil nilai kinerja karyawan diperlakukan secara detail sesuai dengan ketntuan yang sama seperti skala penilaian dan bobot nilai.

3. Semakin Gap yang dihasilkan karyawan semakin kecil maka bobot nilai semakin besar dan karyawan berpeluang lebih besar untuk dapat dipromosiakn jabatannya.

Ucapan Terima Kasih (or Acknowledgement) jika ada/ optional

Penulis mengucapkan terimakasih kepaa Allah SWT atas semua nikmat yang telah diberikan dan kelancaran dalam menulis jurnal ini. Keluarga tercinta dan Sekolah Tinggi Ilmu Komputer CKI

\section{Referensi (Reference)}

1. oleh Munawir dan Ardiansyah yang berjudul “ Decision Support System Pemilihan Karyawan Berprestasi Dengan Pendekatan Analisa Gap Profile Matching Di Kantor Perwakilan Bank Indonesia Provinsi Aceh" jurnal Teknoogi Informasi dan Komunikasi 1 (1)2017 7-14

2 Brian Aif Maulana dkk yang berjudul "Sistem Pendukung Keputusan pemilihan BEST AGENT dengan Metode Profile Matching (GAP)” Jurnal Teknologi Informasi Vol. 5 No. 12019

No ISSN : 2480-2108 dan E-ISSN : 2820-5181.

3. Yohanis Malelak yang berjudul "Sistem Pendukung Keputusan Ususlan Kenaikan Pangkat dan Golongan dengan Menggunakan Metode GAP Pada Dinas Kebudayaan dan Pariwisata Provinsi Nusa Tenggara Timur" JTRISTE Vol. 32016

4. Adiyanto dan Devi Sahara yang berjudul "Penerapan Metode GAP pada Sistem Pendukung Keputusan kenaikan Jabatan Di PT. KMK Global Sport” Jurnal IPSIKOM Vol.6 2018

5. Merry Agustinayang berjudul "Implementasi Metode Gauging Absence Of Prerequistes (GAP) Pada Sistem Penilaian Kinerja (Performance Appaisal) Karyawan PT. XYZ" Proseding Seminar Bisnis dan Teknologi

6. Sofyan Huda dkk yang berjudul "Sistem Pendukung Keputusan Kelayakan Produk Contoh Pada PT. Roi Surya Prima Farma (Studi perbandingan Metode SAW dan GAP Analisis)" Teknik Informasi fakultas Teknik Universitas Widyagoma

7. Yely Yosiana dkk yang berjudul "Implementasi Metode Analisis GAP dan Profile Matching Untuk Kelayakan Calon Debitur di Koperasi Simpan Pinjam (KP) Kopdit Solidaritas Santa Maria Assumpta" J-ICON Vol.7 2019

8. Apriana Panca Kartikasari dkk yang berjudul "Sistem pendukung Keputusan Untuk Penilaian Kinerja Pegawai dengan Metode GAP (Profile Matching) Berbasis Web Studi kasus : Batik Baenang Ratu" Prosding SINTAK 2019

9. Andrian Setiawan dkk yang berjudul "Implementasi Metode Analisis GAP dan Profile Matching untuk Seleksi Penerimaan Penyiar Radio (Studi Kasus PT Radio Swaraunib FM)" Jurnal Rekursif Vol.3 2017 
DOI: 10.52362/jmijayakarta.v1i4.572

10. Riska Shoumil Ilham dkk yang berjudul "Penilaian Kinerja Karyawan dengan Metode AHP dan Rating Scale" Jurnal Optimasi Sistem Industri Vo.16 2017

11. Wahyu Maulana yang berjudul "Pengaruh Promosi jabatan, Kompensasi dan Stres Kerja Terhadap Kinerja Karyawan PT. TEMA (Trijaya Excel Madura) melalui Kepuasan Kinerja” Business Management Analysis Journal Vol.2

12. subhan Akbar Diwanda dkk yang berjudul "Sistem Pendukung Keputusan Penilaian Kinerja Karyawan Menggunakan Metode Multifactor Evalution Proces Pada PT. Konsul Wilayah Sulawesi Tenggara" SemanTIK Vol 2.

13Bixon Natanael dkk yang berjudul 'Analisis dan Perancangan Sistem Informasi Penelitian Kinerja Karyawan Pada PT. BPR Universal Sentosa” Sistem Informasi STIKOM Dinamika

14. Kevin Tangkuman dkk yang berjudul "Penilaian Kinerja, Reward dan Punishment Terhadap Kinerja Karyawan Pada PT. Pertamina (Persero) Cabang Pemasaran Suluttenggo" Jurnal EMBA Vol 3. 